\title{
A critical comparison of techniques for estimating bacterial abundance on leaf litter decaying in Oued Zegzel (Morocco)
}

\author{
A. Maamri ${ }^{1}$
}

Keywords : homogenisation, direct count, stomacher, sonication, bacteria, decaying leaves.

A critical comparison of four techniques used to estimate the abundance and biomass of bacteria associated with leaves decaying in a small river in the North-East of Morocco is given. The relative efficiency of the four methods was as follows: homogenisation $>$ direct count $>$ stomacher $>$ sonication. However, each one of these techniques presents its advantages and disadvantages. No technique is perfect by itself.

Comparaison critique des techniques utilisées pour estimer l'abondance bactérienne sur les feuilles en décomposition dans l'Oued Zegzel (Maroc)

Mots clés : homogénéisation, comptage direct, stomacher, sonication, bactéries, feuilles en décomposition.

L'article présente une comparaison critique de quatre techniques utilisées pour estimer l'abondance et la biomasse des bactéries associées aux feuilles mortes en décomposition dans une petite rivière du nord-est du Maroc.

L'efficacité relative des quatre techniques se présente, par ordre décroissant, comme suit : homogénéisation > comptage direct $>$ stomacher $>$ sonification. Cependant, chacune de ces techniques présente ses avantages et ses inconvénients. Il n'existe pas de techniques absolues.

\section{Introduction}

Recent work has focused on the double role played by bacteria and fungi, as well in the sediment as on organic plant matter. Fungi and bacteria do not only mineralise organic compounds, a role which was classically ascribed to them, but also produce biomass available for the higher trophic levels (Azam et al. 1983, Sherr et al. 1987).

Hence it is necessary to describe the distribution of microbial populations attached to decomposing leaves in order to better understand the transformation of organic matter in aquatic environments. This description requires the estimation of biomass on the leaves at a given time. It would be of great interest, in the field of

1. Laboratoire d'Hydrobiologie \& Ecologie Générale, Faculté des Sciences, Oujda, Morocco.

<E-mail: maamri@sciences.univ-oujda.ac.ma> microbial ecology, to have a precise and reliable method for estimating these parameters. Unfortunately, no entirely satisfactory method for measuring bacterial biomass in natural environments seems to exist.

Counting bacterial cells by means of epifluorescent microscopy is currently considered the best approach to estimating abundance and biomass in aquatic systems. Bacteria attached to particles can be counted either directly on the particle surface or after detachment from their substrate. Different procedures for detachment have been proposed but there is some debate in microbial ecology as to which approach and procedure is the most efficient. This is the issue that this study adresses. It compares three procedures for detaching bacteria from leaves decaying in a stream in Morocco with direct counts of bacterial cells on leaf surfaces.

\section{Material and methods}

Newly-fallen leaves of Salix pedicellata and Nerium oleander were collected from the ground on the banks 
of the Southwest Branch of Oued Zegzel in the Beni Snassen mountain ridge (northeastern Morocco) in October 1998. This headwater stream has the fastest litter breakdown rates in the whole catchment (Chergui \& Pattee 1993, Maamri et al. submitted). At this location the deciduous and soft $S$. pedicellata leaves had a mean daily exponential breakdown rate of 0.0094 and the tough and toxic perennial leaves of $N$. oleander had a mean daily breakdown rate of 0.0084 (Maamri et al. submitted and yet unpublished data). Five-g packs of these fresh leaves were enclosed in bags with $2 \mathrm{~mm}$ meshes. Starting on 1 November, 24 packs were exposed in the stream during 60 days to allow their colonisation by bacteria. At the end of this time, the leaves were recovered and transported to the laboratory in ice to compare four techniques for counting the bacteria. Three replicate packs of each leaf species were processed as follows by each method.

\subsection{Stomacher}

The stomacher (Sigma Seward Stomacher 80) had a maximum volume capacity of $80 \mathrm{ml}$. It had three rates of operation (fast, normal, slow), and the "normal" rate (Fry et al. 1985) was used in this work. Forty $\mathrm{ml}$ of water with $2 \mathrm{ml}$ of $2 \%$ formaldehyde were filtered on $0.22 \mu \mathrm{m}$ nucleopore filters (diameter $=2 \mathrm{~cm}$ ). Two or three leaves were introduced into special sterile bags and placed in this solution. The stomacher was worked for $20 \mathrm{~min}$. Then coarse particles were removed by straining through $250-\mu \mathrm{m}$ filters. A $0.1 \mathrm{ml}$ subsample was taken and completed to a final volume of $10 \mathrm{ml}$. Next, four $\mathrm{ml}$ of filtrate were again filtered on a GTBP Millipore filter (pores of $0.2 \mu \mathrm{m}$ ) and $0.5 \mathrm{ml}$ of a 0.1 $\mathrm{mg} \cdot \mathrm{ml}^{-1}$ solution of acridine orange was added on these filters. After 15 minutes' incubation, the filters were rinsed with distilled water to remove the excess of staining solution (Fry 1988) and examined under immersion oil with a Leitz DIALUX 22 microscope. Three microscopic preparations from the leaves of each pack (9 filters) were examined.

\subsection{Sonication}

Twelve discs with a diameter of $10 \mathrm{~mm}$ were cut immediately after collection from 2 or 3 leaves of each bag (Salix and Nerium). The discs were immersed in $20 \mathrm{ml}$ distilled and filtered (nucleopore with pores of $0.22 \mu \mathrm{m}$ ) water, to which $2 \mathrm{ml}$ of $2 \%$ formaldehyde had been added. They were sonicated in a Transsonic T570/H bath for 3 minutes (Velji \& Albright 1985, modified, Pierzo et al. 1994). Then $4 \mathrm{ml}$ of the suspension were used for filtering and staining the bacteria and microscopic epifluorescence observation was performed as described above.

\subsection{Homogenisation}

Twelve $10 \mathrm{~mm}$ diameter discs were cut from leaves of each pack. These discs were immersed and stocked in $5 \mathrm{ml}$ distilled and filtered (nucleopore with pores of $0.22 \mu \mathrm{m}$ ) water, to which $2 \mathrm{ml}$ of $2 \%$ formaldehyde had been added. To each sample were added $5 \mathrm{ml}$ of sterile $(0.22 \mu \mathrm{m}$ filtration) distilled water in which the samples were ground manually with a Tenbroeck mortar and pestle for 3 minutes. Then they were diluted with $20 \mathrm{ml}$ of sterile water, stirred in a vortex and left to settle for one minute (Suberkropp \& Klug 1976). A $0.1 \mathrm{ml}$ subsample was taken and completed to a volume of $10 \mathrm{ml}$. Because this dilution was insufficient to compte bacteria clearly, a second dilution was practised : $1 \mathrm{ml}$ sub-samples of this dilution were taken, diluted to $10 \mathrm{ml}$ (final volume) with sterile water and stirred. Four $\mathrm{ml}$ of each diluted sub-sample were filtered for counting the bacteria with acridine orange as explained above.

\subsection{Direct count without detachment}

After staining discs with acridine orange $\left(0.1 \mathrm{mg}^{\mathrm{ml}} \mathrm{m}^{-1}\right)$, bacterial densities on the upper and lower surfaces of nine $10 \mathrm{~mm}$ diameter discs were determined in 20 randomly-selected microscopic fields (100 x objective).

\subsection{Statistical analysis}

Values were converted to bacteria per $\mathrm{cm}^{2}$ of upper leaf area. Bacterial numbers were compared by twoway ANOVA (bags and methods). Data were squareroot transformed before statistical analysis.

\section{Results and discussion}

In the stream, the bags excluded most invertebrates, but some very small Melanopsis praemorsa (Gastropoda) shredders were able to pass through the meshes and grow for two months inside the bags. Hence some ingestion of bacteria may have occurred.

The slower-decaying $N$. oleander leaves consistently carried more bacteria and the difference was highly significant $(\mathrm{p}<0.01)$. Initial colonisation of the oleander leaves may have been greater, or more browsing by shredders may have occurred on the willow leaves. A former study showed a similar difference between most oleander and willow leaves in the lower course of the same river (Maamri et al. 1999).

For both leaf species, there was a highly significant difference between the four methods ( $p<0.001$ ). Homogenisation and direct count without detaching the bacteria yielded the greatest numbers (Fig. 1) and the relative efficiency of the four methods was as follows : 
homogenisation $>$ direct count $>$ stomacher $>$ sonication.

Moreover the interaction between leaf species and methods was also highly significant $(\mathrm{p}<0.01)$. Fig. 1 shows that homogenisation and direct counts revealed greater differences in bacterial colonisation between leaf species than the other two methods.

But, obviously, the various approaches presented here are not directly comparable. Each one has its advantages and its disadvantages. The first disadvantage of homogenisation is that it generates many remains which often crowd the microscopic preparations and make counting difficult. Several replicates of the filters must be used. A second problem is that grinding may damage the bacterial cells, which is not compatible with their culture or the measurement of their activities (Fry et al. 1985). Grinding may even cause an over-estimation of bacterial numbers if fragments are counted.

Direct count comes next by its efficiency. Moreover it is fast and cheap (it does not require GTPB filters and prefilters). One disadvantage is that, at the beginning of microbial colonisation, the bacteria are not uniformly distributed on the surface of the leaves. Hence it is necessary to observe several discs cut from various parts of the leaves. At the end of breakdown, the estimation of numbers per unit leaf area may become difficult, but then bacterial numbers are usually low (Maamri et al. 1999).

The stomacher makes the processing of whole leaves possible and does not break up bacteria but it generates masses of remainders and requires their dilution.

Bath sonication was least efficient for detaching the bacteria from the leaves, as also noted by Donegan et al. (1991). Sonication can harm bacteria and its efficiency for dislodging internal bacteria is low (Maamri et al. 1999).

Some data from the literature recording bacterial numbers on submerged leaves are given in Table 1. Comparisons can only be very approximate because leaf species and incubation conditions (duration of exposure, climate, environments) were different.

Homogenising often yielded high numbers of bacteria $\left(10^{8}-10^{9}\right)$. The lower numbers found by Newell et al. (1989) were on tidally dry and flooded marsh cordgrass. The highest numbers were recorded in the present study.

Direct counts also yielded high numbers but ranked second, as in the present study whose results are in agreement with those of the literature.

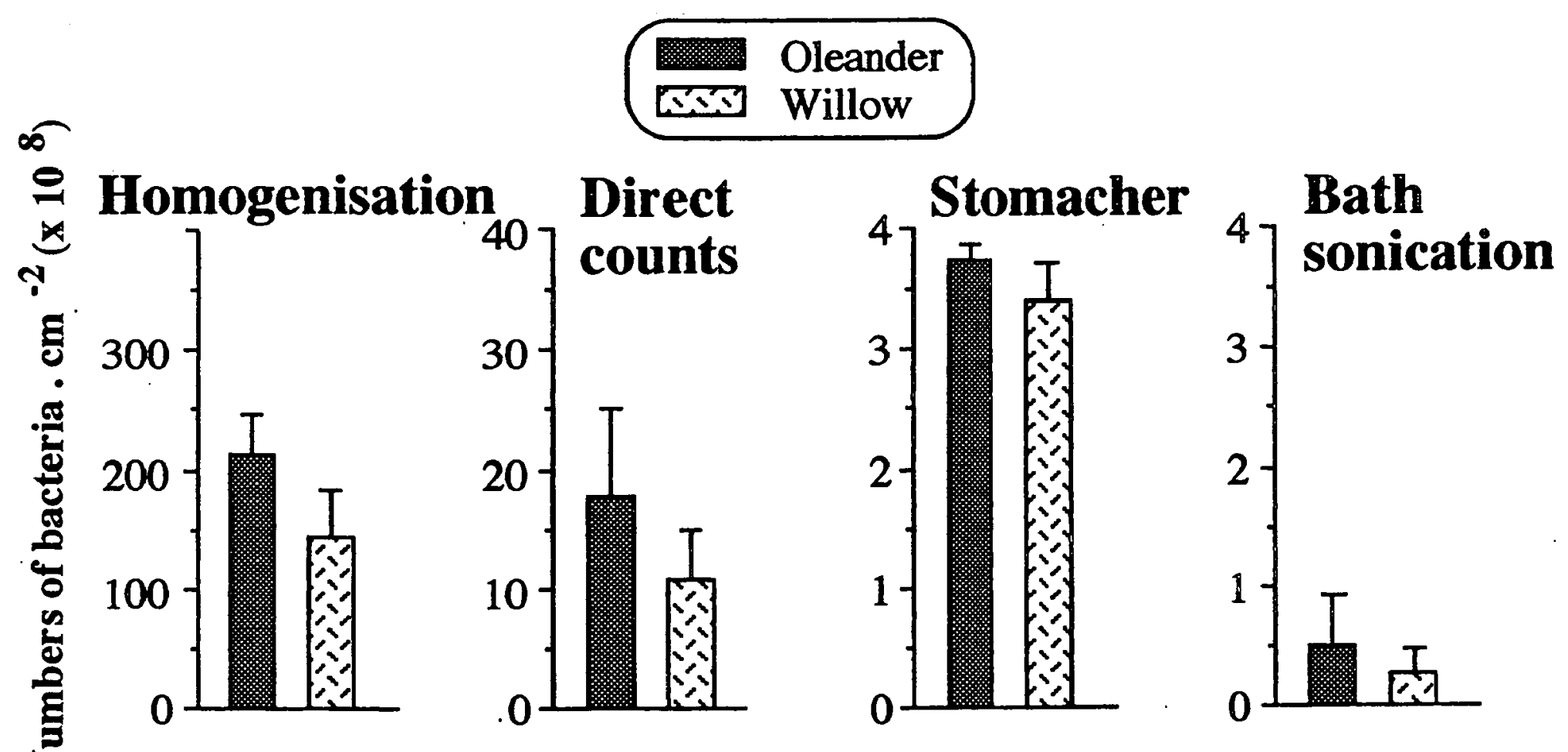

Fig. 1. Numbers of bacteria on $N$. oleander and $S$. pedicellata leaves decaying in the Upper Zegzel as estimated by four different techniques. Note the different ordinate units. Error bars indicate Standard deviation $(\mathrm{N}=9)$.

Fig. 1. Nombre des bactéries sur les feuilles de $N$. oleander et $S$. pedicellata en décomposition à l'amont du Zegzel, estimé par quatre techniques différentes. Noter la différence d'échelle. Les barres d'erreurs indiquent la déviation standard $(N=9)$. 
Table 1. Some data from the literature reporting bacterial numbers on dead leaves.

Tableau 1. Quelques données de la littérature sur le nombre des bactéries présentes sur les feuilles mortes.

\begin{tabular}{ccccc}
\hline $\begin{array}{c}\text { Numbers of bacteria } \\
\left.\text { (bacterial cells } . \mathrm{cm}^{-2}\right)\end{array}$ & Method of extraction & Leaves & Stain & Authors \\
\hline $6.3 \times 10^{*}$ & Homogenisation & Smooth cordgrass & Acridine orange & Newell \& Hicks (1982) \\
$10^{7}$ & Homogenisation & Smooth cordgrass & Acridine orange & Newell et al. (1989) \\
$2 \times 10^{8}$ & Homogenisation & Willow, poplar and plane & DAPI & Baldy et al. (1995) \\
$1.5-2.1 \times 10^{10}$ & Homogenisation & Willow and oleander & Acridine orange & This paper \\
$6 \times 10^{6}$ & Directcount & Maple & NH4 ANS & Tam et al. (1983) \\
$0.58-3.4 \times 10^{7}$ & Direct count & Watercress and starwort & Phenolic aniline blue & Fry et al. (1985) \\
$8 \times 10^{9}$ & Direct count & Birch and maple & Acridine orange & Sridhar \& Baerlocher (1993) \\
$1.1-1.8 \times 10^{9}$ & Direct count & Willow and oleander & Acridine orange & This paper \\
$8.4-23 \times 10^{6}$ & Stomacher & Watercress & Phenolic aniline blue & Hossel \& Baker (1979) \\
$3.7-14 \times 10^{6}$ & Stomacher & Watercress and starwort & Phenolic aniline blue & Fry et al. (1985) \\
$3.4-3.7 \times 10^{8}$ & Stomacher & Willow and oleander & Acridine orange & This paper \\
$1.5-38 \times 10^{6}$ & Sonication & Kelp & DAPI & Velji \& Albright (1985) \\
$5 \times 10^{6}$ & Sonication & Smooth cordgrass & Acridine orange & Newell \& Palm (1998) \\
$1-8 \times 10^{6}$ & Sonication & Willow and oleander & Acridine orange & Maamri et al. (1999) \\
$0.5-2.5 \times 10^{7}$ & Sonication & Willow and oleander & Acridine orange & This paper \\
\hline
\end{tabular}

* estimated from numbers per dry mass.

Stomacher and sonication results were lower. But in the present paper the stomacher gave values 100 times greater than the earlier ones (Hossel \& Baker 1979, Fry et al. 1985) and bath sonication gave values 10 times greater than the other ones, two of which (Velji \& Albright 1985, and Newell \& Palm 1998) were obtained with probes and one (Maamri et al. 1999) with a bath.

Büsing, Griebler \& Gessner (pers. comm.) dislodged most bacteria from leaf litter with an ultrasonic probe. Next came an Ultraturrax which gave more variable results. An ultrasonic bath came third and the efficiency of the stomacher was lowest. But detachment efficiency of these four instruments was quite different on sediment, on which the stomacher yielded the highest numbers.

\section{Conclusion}

This comparison of methods for estimating bacterial numbers shows that, as noted by Kepner \& Pratt (1994), there is no perfect technique and that an ecolo- gical evaluation is safer when several techniques are applied together.

\section{Acknowledgment}

Hearty thanks to my wife, S. Ben El Mostafa, who operated the stomaching in her laboratory.

\section{References}

Azam F., Fenchel T., Field J.G., Gray J.S., Meyer-reil L.A. \& Thingstad F. 1983. - The ecological role of water column microbes in the sea. Mar. Ecol. Progr. Ser., $10: 257-263$.

Baldy V., Gessner M.O. \& Chauvet E. 1995. - Bacteria, fungi and the breakdown of leaf litter in a large river. Oikos, $74: 93-102$.

Chergui H. \& Pattee E. 1993. - Fungal and invertebrate colonization of Salix fresh and dry leaves in a Moroccan river system. Arch. Hydrobiol., $127:$ 57-72.

Donegan K., Matyac C., Seidler R. \& Porteous A. 1991. - Evaluation of methods for sampling, recovery and enumeration of bacteria applied to the phylloplane. Appl. environ. Microbiol., 57 : 51-56.

Fry J.C. 1988. - Determination of biomass. In : Austin B. (Ed.), Methods in aquatic bacteriology-Wiley, New York : 27-72.

Fry J.C., Goulder R. \& Rimes C.A. 1985. - A note on the efficiency of stomaching for the quantitative removal of epiphytic bacteria from submerged aquatic plants. J. appl. Bacteriol., 58 : 113-115. 
Hossel J.C. \& Baker J.H. 1979. - A note on the enumeration of epiphytic bacteria by microscopic methods with particular reference to two freshwater plants. J. appl. Bacteriol., $45: 87-92$.

Kepner R.L.Jr \& Pratt J.R. 1994. - Use of fluorochromes for direct enumeration of total bacteria in environmental samples : past and present: Microb. Rev., $58: 603-615$.

Maamri A., Bärlocher F., Pattee E. \& Chergui H. (in press). - Fungal and bacterial colonisation of Salix pedicellata leaves decaying in permanent and temporary streams in eastern Morocco. Internat. Rev. ges. Hydrobiol.

Maamri A., Pattee E., Gayte X. \& Chergui H. 1999. - Microbial dynamics on decaying leaves in a temporary Moroccan river. IIBacteria. Arch. Hydrobiol., 144 : 157-175.

Newell S.Y., Fallon R.D. \& Miller J.D. 1989. - Decomposition and microbial dynamics for standing, naturally positioned leaves of the salt-marsh grass Spartina alterniflora. Mar. Biol. (Berlin), $101: 471-481$.

Newell S.Y. \& Hicks R. E. 1982. - Direct estimates of fungal and bacterial biovolume in dead leaves of smooth cordgrass (Spartina alterniflora Loisel.). Estuaries, 5 : 246-260.
Newell S.Y. \& Palm L.A. 1998. - Responses of bacterial assemblages on standing-decaying blades of smooth cordgrass to additions of water and nitrogen. Internat. Rev. ges. Hydrobiol., 83 : 115-122.

Pierzo V., Ballahcen D., Fontvieille D., Lazarova V., Huyard A. \& Manem J. 1994. - Improved procedure for wastewater removal and analysis. Colloids and Surfaces B : Biointerfaces, 2 : 577584.

Sherr E.B., Sherr B. F. \& Mcdaniel J. 1987. - Bacteria : link or sink? Nature, $235: 88-89$

Sridhar K.R. \& Bärlocher F. 1993. - Seasonal changes in microbial colonization of fresh and dried leaves. Arch. Hydrobiol., 128 : $1-12$.

Suberkropp K. \& Klug M.J. 1976. - Fungi and bacteria associated with leaves during processing in a woodland stream. Ecology, $57: 707-719$.

Tam T.Y., Mayfield C.I. \& Inniss W.E. 1983. - Microbial decomposition of leaf material at $0^{\circ} \mathrm{C}$. Microbial Ecol., $9: 355-362$.

Velji M.I. \& Albright L.J. 1985. - Microscopic enumeration of attached marine bacteria of seawater, marine sediment, fecal matter and kelp blade samples following pyrophosphate and ultrasound treatments. Can. J. Microbiol., 32: 121-126. 